\title{
A rainfall data analysis for the archeological drawing of the Augustan aqueduct route
}

\author{
Francesco De Paola ${ }^{a}$, Maurizio Giugni ${ }^{a}$, Maria Emanuela Cornacchia ${ }^{\mathrm{b}}$, \\ Giovanni Libralato ${ }^{c}$, Giusy Lofrano ${ }^{\mathrm{a}, \mathrm{d}, \mathrm{e}, *}$ \\ a Department of civil, architectural and environmental engineering, university of Naples "Federico II", 21, via Claudio, 80125 Naples, Italy \\ b TBC Générateur d'innovation, 25, boulevard Victor-Hugo, 31770 Colomiers, France \\ c Department of environmental sciences, informatics and statistics, university Cà Foscari Venice, 2737/b, campo della Celestia, 30122 Venice, Italy \\ ${ }^{\mathrm{d}}$ Department of chemistry and biology, university of Salerno, 132, via Giovanni Paolo II, 84084 Fisciano (Sa), Italy \\ e Institute of methodologies for environmental analysis, national research council (CNR IMAA), C. da S. Loja Z.I. Tito Scalo, 85050 Potenza, Italy
}

\section{A R T I C L E I N F O}

\section{Article history:}

Received 24 September 2015

Accepted 25 January 2016

Available online 12 February 2016

\section{Keywords:}

Cumae

Naples

Roman bath

Augustan aqueduct

Water supply

\begin{abstract}
A B S T R A C T
Was Cumae supplied by the collection of rainwater, widely practiced for long time in the Mediterranean area, or by a branch of the Augustan Aqueduct? The main goal of Aqua Augusta was to provide water to Puteoli (civilian) and Misenum (military) that were two of the main harbors of the Empire. However, the ruins of the branch that would have flowed through Cumae have not been excavated yet. The aqueduct structure has not been studied in detail due to the difficulty in inspecting and the missing arches. A rainfall data analysis was carried out to assess the flow and use of the water conveyed by the Aqua Augusta aqueduct to Cumae. Results indicated that rainwater was not sufficient to supply Cumae and the Aqua Augusta should have played a great role in delivering water to the city.
\end{abstract}

(C) 2016 Elsevier Masson SAS. All rights reserved.

\section{Introduction}

Traditionally, the archaeology of water has been formerly focused on the aesthetic and architectural features of hydraulic works rather than on technical and mechanical aspects [1]. Over the centuries, civilizations developed structures to bring drinking water to the population centers, especially through the use of aqueducts. There are many historical records on the purpose and design of aqueducts. Many of these aqueducts, though thousands of years old, are still standing [2]. Although the crucial importance of water is well known, water supply has not been considered as particularly interesting [3-5]. The great bridges constitute an exception like the long arcades of Roman aqueducts, which continue to enrich the landscape of countryside and cities all around Europe (e.g. Pontdu-Gard, France). Surprisingly, engineering and aesthetic issues were always effectively conjugated. Whenever possible Roman engineers followed, the steady downhill course at/or belowground level for constructing aqueducts [6-9]. Rome's aqueduct system

\footnotetext{
* Corresponding author. Tel.: +39 3397117349; Fax: +39 0815938936.

E-mail addresses: depaola@unina.it (F.De Paola),ing.m.e.cornacchia@gmail.com (M.E. Cornacchia), giovanni.libralato@unive.it (G. Libralato), glofrano@unisa.it, giusylofrano@gmail.com (G. Lofrano).
}

was underground by approximately $87 \%$ [3]. Many of these sections were deep tunneled through limestone and tufa rock. Others were excavated into the hillside with an engineered rock and mortar tunnel set into the excavation and then backfilled with the native soil [10-12]. Thus, the study of their routes is not an easy task to carry out, as in the case of the double-branched Augustan Aqueduct (Aqua Augusta) built in Campania Region between 20 and 30 $\mathrm{AD}$ [13]. The former branch gushed from the spring of Serino located in the Terminio-Tuoro Mountain taking water up to Benevento. The other branch originated at "Acquaro-Pelosi", still from Serino spring, feeding Misenum [11]. The former and almost entirely underground branch was $103 \mathrm{~km}$ long having many secondary branches being $60 \mathrm{~km}$ long. A section of Aqua Augusta, the longest aqueduct of the Roman Empire [12], was brought to light in February 2012 by a landslide occurred after a heavy snowfall [14]. The first historical survey of its open-air route and the deep-tunneled sections was carried out by Abate [15] in order to assess the possibility of using the ancient tunnels for a new aqueduct supplying the City of Naples. Nowadays, the study of the original route of the aqueduct cannot be considered concluded. Unfortunately, the Aqua Augusta has not been sufficiently investigated for the following reasons:

- the structure is mostly underground and inspections are difficult;

- it is not considered of architectural interest. 


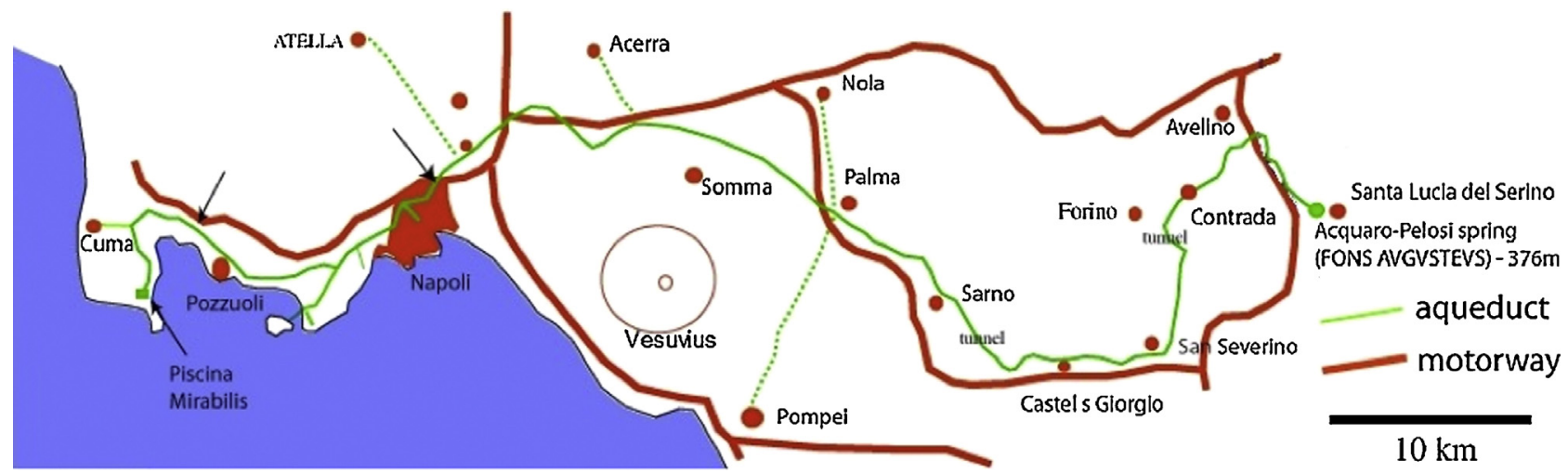

Fig. 1. Location of Cumae along the route of the Augustan aqueduct from Serino to Miseno.

Adopted from De Feo et al. [31].

An inscription, attesting its repair at the time of Constantine the Great (324/326 AD), indicated that the aqueduct served the cities of Puteoli, Neapolis, Nola, Atella, Cumae, Acerrae, Baia Misenum and the coastal cities of Vesuvius (Pompei and Hercolanum). The ruins of this branch flowing through Cumae have not been excavated yet, so there is no real proof of its route [11].

Cumae (Cuma archeological site, No.40.848356, E 14.054078) is located on the northern edge of Campi Flegrei (Naples, Campania Region, Italy), facing south and parallel to the Domitian coast (Fig. 1).

The settlement was established by Greek colonists in the VIII Century BCE, sacked by Oscans in the V Century BCE and incorporated into the Roman Empire in the IV Century BCE [16]. Nowadays, the most celebrated site at Cumae is the Sybil's Cave, the Archaeological Park houses, a series of ancient ruins and artefacts, including two Roman baths and various tunnels and cisterns. Baths were popular places of mass resort and the first sanitary facilities, being standard equipment in modern houses, but they were often not included in ancient roman dwellings. The main scope of Roman aqueducts was to fed baths continually [3]. Manderscheid [7] assumed that since the thermal baths were located outside cities, accomodations for housing and feeding patients must have been furnished. According to him, since the relative temperatures of the springs vary considerably between $26^{\circ} \mathrm{C}$ and $70^{\circ} \mathrm{C}$, there must have been some provisions for cooling the water down to a temperature which was beneficial or perhaps comfortable to the human body. Indeed, in only a very few cases would the water have automatically cooled off sufficiently on its way from the source to the bathing pools. The archeology evidence reveals two possibilities:

- an installation of cooling into which the water would flow before being introduced into the piscinae;

- the mixing of hot thermal water with fresh water which have must been transported separately over a relatively long distance by means of an aqueduct.

The use of cisterns was very common in roman baths [17]. For instance, in the Baths of Caracalla (Rome), water was supplied by the Aqua Nova Antoniniana and Aqua Marcia aqueducts and local springs and stored in 18 cisterns uring bath time, people gathered daily their social life in an informal context drinking wine and having sexual relationships. Despite the eventual moral disapproval, the popularity of baths endured for over a millennium and spread all over the Roman time $[18,19]$.

The aim of this paper is to investigate the hypothesis that rainwater was not the only water source for Cumae. A statistical analysis of rainfall data was carried out over a 2000 -year period estimating the water demand in Cumae. The analysis considered that between
I - II Centuries AD Cumae experienced an increased water demand due to a great economic, cultural and social growth. Based on the relief of the Cumae Forum bath operated by the authors, two fundamental hypothesis about Cumae water supply system were assessed:

- the collection of rainwater, which had been practiced for long time in the Mediterranean area [19-21];

- the historical records of a branch of the Augustan Aqueduct, which would have reached the city [22].

\section{Methodological approach}

In order to determine whether the forum cistern was supplied with rainwater, the average annual rainfall in Cumae was inferred in the I Century AD using hydrological data from the 1916-1999 annals assuming temporal recurring rainfall events. De Martino et al. [23] supplied further data for the period 2000-2006. There are no data available before 1916 . The rainfall stations chosen for the analysis were located along the border of Cumae that is Pozzuoli, Naples Capodimonte (Observatory), Camaldoli (Hermitage), Ischia (Forio) or Ischia (Porto) and Licola. Rainfall events ranged between $408 \mathrm{~mm}$ (1957) and $1383 \mathrm{~mm}$ (1979).

Due to the complexity of the monthly rainfall analysis and lack of historical data, rainfall estimation was worked out using the value of the average rainfalls inferred by an exponential smoothing state space model starting from the average annual rainfall between 1916 and 2006. This model used a three-character string identifying the framework terminology of Hyndman and Khandakar [24] through $\mathrm{R}$ package forecast. By using ZZZ as default values, the model automatically selected the best model (Additive or Multiplicative) for the error, trend and seasonality of the rainfall series. Two automatic forecasting algorithms were implemented in the forecast package for R [24]. The first one is based on the innovation state space models that underlie exponential smoothing methods. The second is a step-wise forecasting algorithm with Autoregressive integrated moving average (ARIMA) model that is a generalization of an autoregressive moving average (ARMA) model. These models are fitted to time series data either to better understand the data or to predict future points in the series (forecasting).

The algorithms are applicable to both seasonal and non-seasonal data. In order to obtain a robust and widely applicable automatic forecasting algorithm, we followed the following steps:

- application of all models for each series optimizing the parameters (both smoothing parameters and the initial state variable) of the model in each case; 


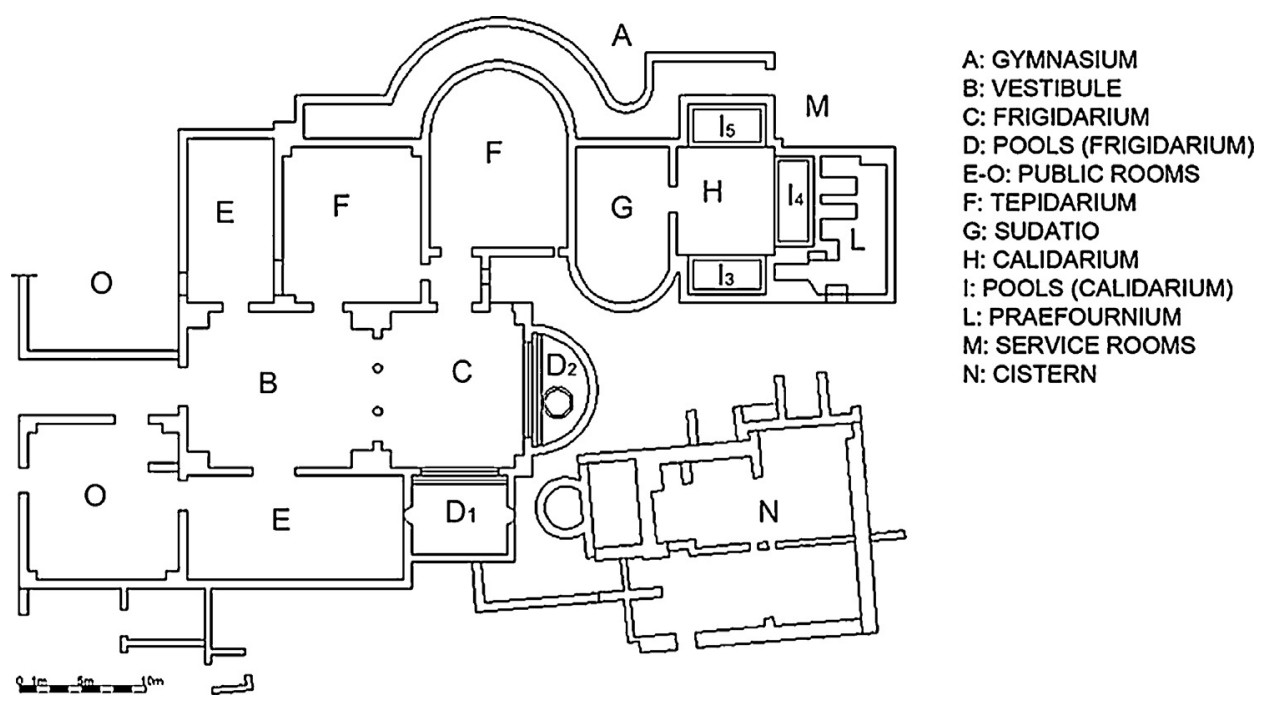

Fig. 2. Topographic survey of forum bath.

- selection of the best model according to the Akaike's information criterion, a measure of the relative quality of statistical models for a given set of data;

- point forecasting using the best model (with optimized parameters) for as many steps ahead as required;

- obtain the prediction intervals for the best model either simulating future sample paths using the normal distribution for errors (parametric bootstrap that is the practice of estimating properties of an estimator (such as its variance) by measuring those properties when sampling from an approximating distribution).

\section{Results and discussion}

\subsection{Route assessment}

\subsubsection{Forum bath description}

Cumae hosted the Forum bath and the smaller Republican Roman bath, known as the Central Roman bath or, improperly, named the "Tomb of the Sibyl" [16]. A topographical survey of the Forum bath is shown in Fig. 2. Its construction dated back to a time of intense building activity, which occurred in Cumae some decades after the construction of via Domitiana (95 AD). At that time, the Central Roman bath was already present in the city centre. The construction of the Forum bath suggested that the population increased as well as the visitors for commercial purposes mainly due to the presence of the port area linked to via
Domitiana, allowing a fast connection to Rome, without the need to reach via Appia [21].

The Forum bath, which remains are shown in Fig. 3a, was located in the lower part of the city. It faced west, most likely to take the advantage of a better insolation at all hours [16]. The two public entrances are shown in Fig. 2:

- the east entrance was located nearby the intersection with the road towards the Forum, along the northern side of the Capitolium;

- the vestibule entrance lead to the frigidarium passing through a scenic colonnade (Fig. 3b).

The frigidarium was characterised by the presence of cold pools. Large windows allowed natural lighting. On the right and left sides of the vestibule, two public spaces were present serving as dressing rooms and for additional activities such as massages and anointing before entering the bath. Southward, a small room served as a corridor preventing heat loss as well as hot rooms. The pools for immersion showed in Fig. 4 were on the north, south and west sides of these rooms.

The bath contained five pools:

- two pools in the frigidarium labelled $\mathrm{D}_{1}\left(31 \mathrm{~m}^{2}\right.$, water depth $1.4 \mathrm{~m}$, volume $\left.43.4 \mathrm{~m}^{3}\right)$ and $\mathrm{D}_{2}\left(21 \mathrm{~m}^{2}\right.$, water depth $1.4 \mathrm{~m}$, volume $29.4 \mathrm{~m}^{3}$ ) accessible through a short staircase (Fig. 4);
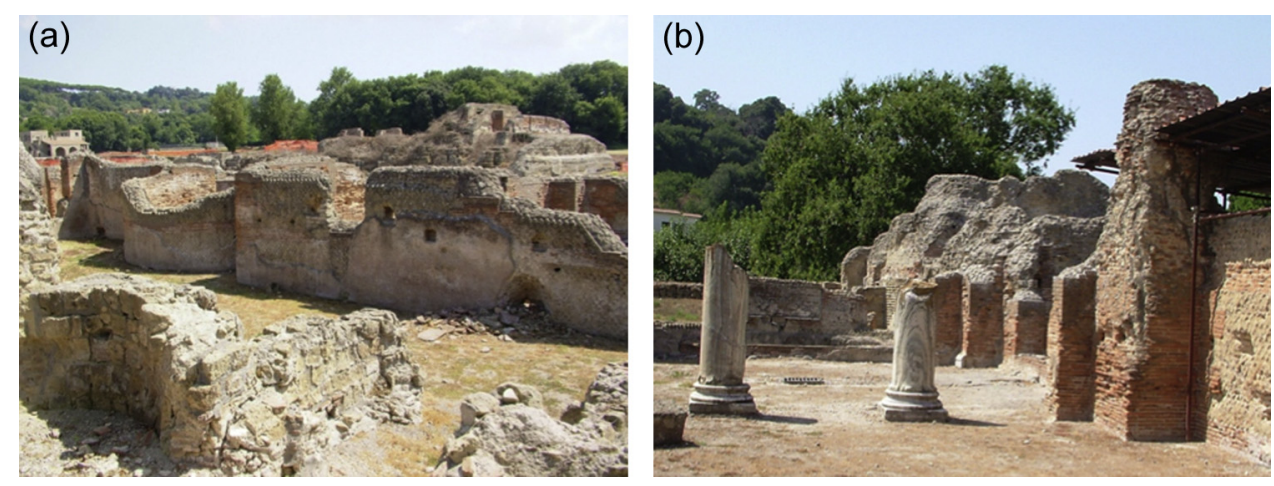

Fig. 3. (a) Remains of forum bath; (b) east entrance of bath and frigidarium. 

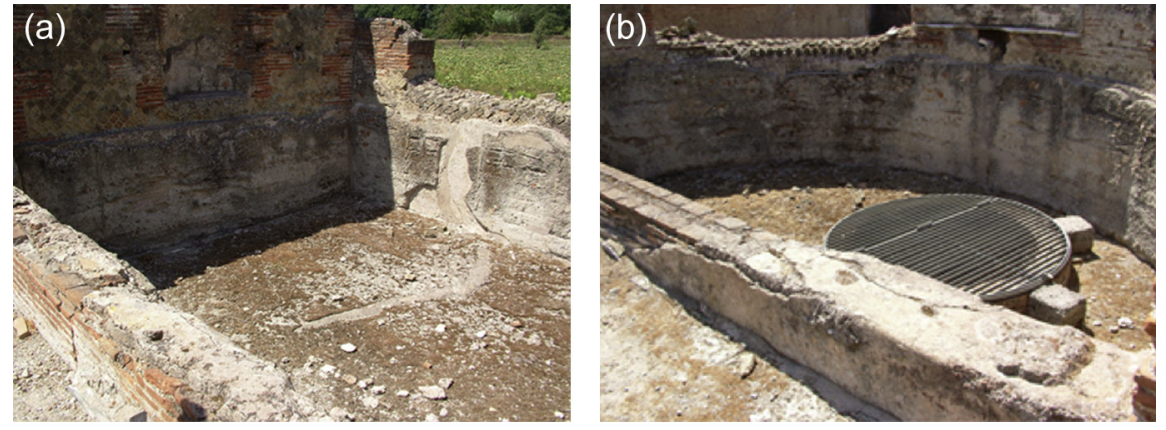

Fig. 4. Pools belonging to the frigidarium - D1 and D2 from Fig. 1.

Pictures taken by the authors.
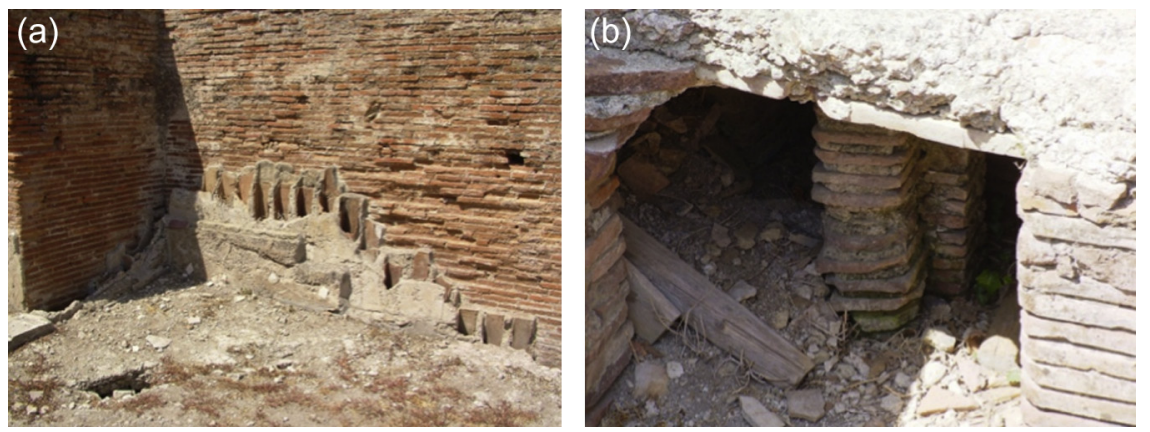

Fig. 5. (a) Tubuli; (b) Suspensurae.

Pictures taken by the authors.

- three inside the calidarium identified $\mathrm{I}_{3}\left(12.5 \mathrm{~m}^{2}\right.$, water depth $1.4 \mathrm{~m}$, volume $\left.17.5 \mathrm{~m}^{3}\right), \mathrm{I}_{4}\left(14.5 \mathrm{~m}^{2}\right.$, water depth $1.4 \mathrm{~m}$, volume $\left.20.3 \mathrm{~m}^{3}\right), \mathrm{I}_{5}\left(13.5 \mathrm{~m}^{2}\right.$, water depth $1.4 \mathrm{~m}$, volume $\left.18.9 \mathrm{~m}^{3}\right)$.

The order of the rooms followed the usual sequence of Roman baths: tepidarium (medium temperature, Fig. 2 [F]), sudatio (for dry heat bath, Fig. $1[\mathrm{G}]$ ), and calidarium (high temperature, Fig. $2[\mathrm{H}]$ ). The heat produced by wood combustion was conveyed from the praefurnium (Fig. 2 [L]) throughout the above-mentioned series of rooms thanks to the tubuli, which was a system of cavities along the walls made of terracotta or brick pipes (Fig. 5a). The decking, lower than that of the adjacent rooms, was at the same level of the praefurnium, with some openings at the same level called the suspensurae, which were part of the floor heating system (Fig. 5b). They were coated with a $15 \mathrm{~cm}$ thick layer of waterproof plaster made of lime mortar mixed with sand or pozzolana and shards of brick [16].

A cistern, placed on a pedestal in the northwest corner of the bath, supplied water. The pedestal was located about $2 \mathrm{~m}$ over the base of the pools to facilitate the distribution of water. The cistern, originally divided into four tanks, was orientated in a way slightly different from that of the main complex. From the ruins' investigation, the cistern was $15 \mathrm{~m}$ long, $13 \mathrm{~m}$ width and $4.5 \mathrm{~m}$ depth (Fig. 6). Its perimeter wall had a thickness greater than that of the rest of the Roman bath (minimum thickness of $1 \mathrm{~m}$ ), while the partition walls between tanks were thinner. The walls were primarily composed of opus reticulatum, interrupted at half height by eight rows of opus latericium (Fig. 6), covered with a thick layer of over $15 \mathrm{~cm}$ thick impermeable plaster. The plaster formed the pier caps at the corners between the wall and the floor, according to a technical solution common to both the ancient cisterns and modern tanks.

The cistern of the bath in the Forum operated as a castellum aquae, since it was positioned about $2 \mathrm{~m}$ higher than the bottom of the pools. The net area of the cistern was about $150 \mathrm{~m}^{2}$; assuming an interior water level of $3.50 \mathrm{~m}$, it could have contained about 525 $\mathrm{m}^{3}$ of water. The assumption of considering an interior water depth of $3.5 \mathrm{~m}$ from the total height of the cistern $(4.5 \mathrm{~m})$ was adopted on the base of estimated literature values [25]. The total area and volume of the pools were $92.5 \mathrm{~m}^{2}$ and $129.5 \mathrm{~m}^{3}$, respectively. Therefore, the cistern volume was about four times greater than the amount of water necessary to fill the pools.

\subsubsection{Rainfall data analysis}

Results from the rainfall inference analysis suggested that:

- generally, a rainy year followed a drier one;

- annual values fluctuated in a periodic way with an average of $825 \mathrm{~mm}$ of rainfall (Fig. 7).

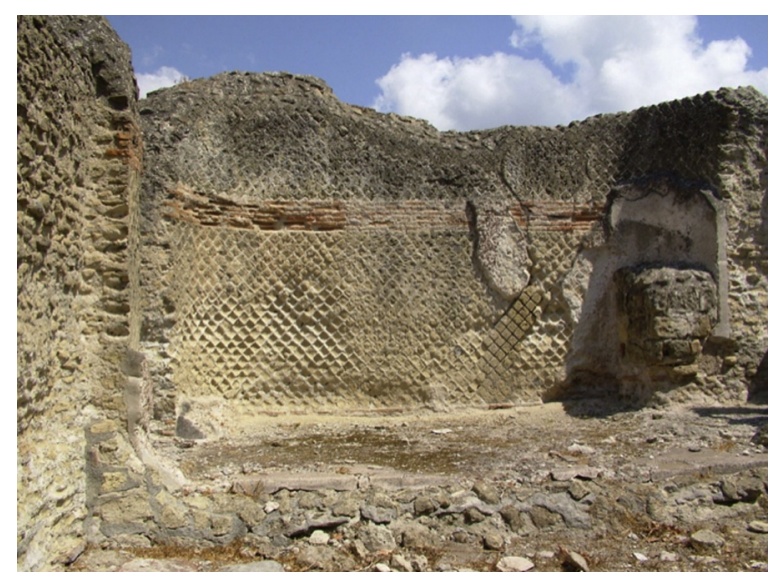

Fig. 6. Cistern feeding the pools.

Pictures taken by the authors ( $N$ in Fig. 1). 


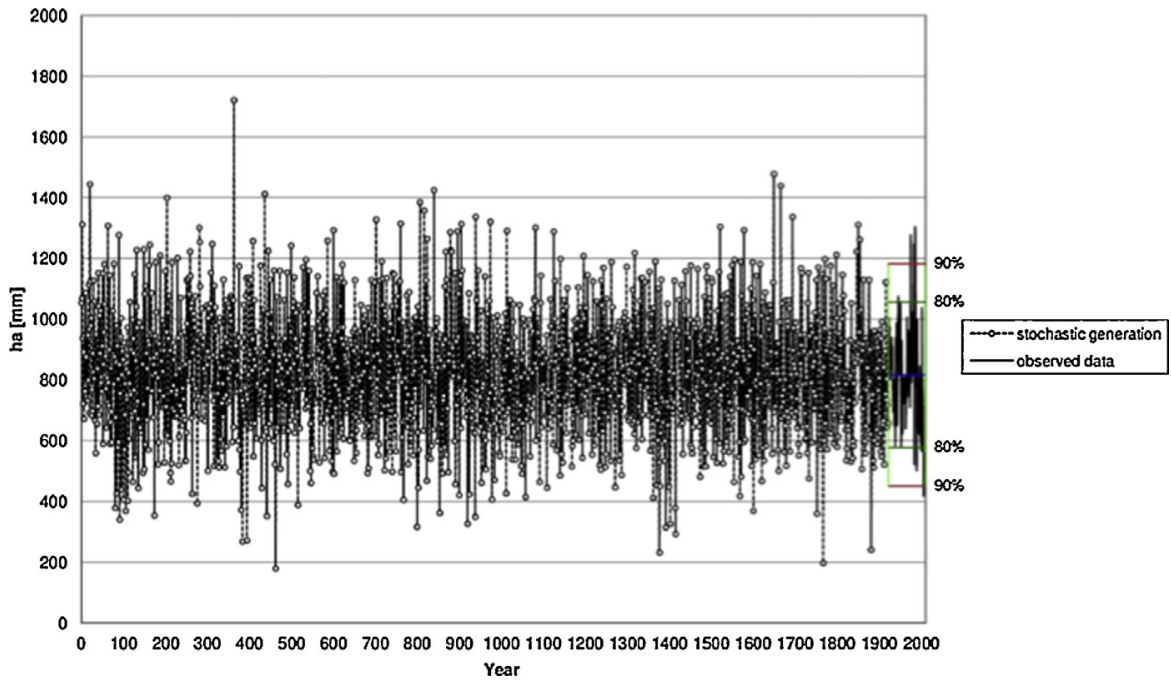

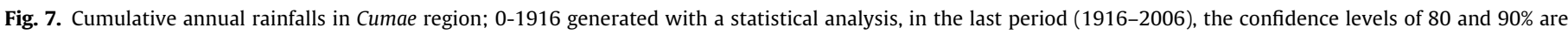
reported with the observed data [24].

Considering the hypothesis of rainwater use and taking into account an average annual rainfall of $825 \mathrm{~mm}$, the total average water volume that could have been potentially accumulated per year in the cistern was:

$V=S_{c} \bullet h_{m}=150^{\bullet} 0.825=123.75 \mathrm{~m}^{3}$

where $S_{c}$ is the net area of the cistern and $h_{m}$ the averge of rainfall. The maximum water volume was $207.48 \mathrm{~m}^{3}$ (with an increase of about $67 \%$ !) considering the rainiest year.

Thus, these volumes were insufficient even to fill the pools once per year. The statistical hydrological analysis of rainfall data over around 2000 years (Fig. 8) showed the reconstructed data between 0 and 1916 with a forecast confidence level of $80 \%$ and 90\% (Fig. 6) harvesting rainfall data within 1916-2006 (Fig. 8). The maximum forecasted value of the cumulative annual precipitation was approximately $1,800 \mathrm{~mm}$; therefore, no more than one tank of $270 \mathrm{~m}^{3} /$ year could have been filled. Although roof run-off could be conveyed to the tank, its contribution was negligible compared to the total volume.
As a consequence, the rainfall analysis confuted the hypothesis of the exclusive use of rainwater, suggesting that the Augustan Aqueduct supplied Cumae.

\subsection{Flow assessment}

The number of Cumae inhabitants during the first and second centuries AD is unknown to historians or archaeologists. The available records did not provide accurate data for the historical reference period and most of the town were not excavated. Thus, a calculation of the daily flow based on the available water supply per capita and the number of inhabitants is not possible.

Data derived from the characteristics of Roman bath and the volume of cisterns was used to determine both baths' water consumption and the potential daily number of visitors [30]. From these values, a rough estimation of the number of people present in Cumae and the flow delivered from the aqueduct to the city resulted feasible.

Assuming that the baths were open until sunset, a daily functioning of $12 \mathrm{~h}$ is plausible. The total submersion time of each

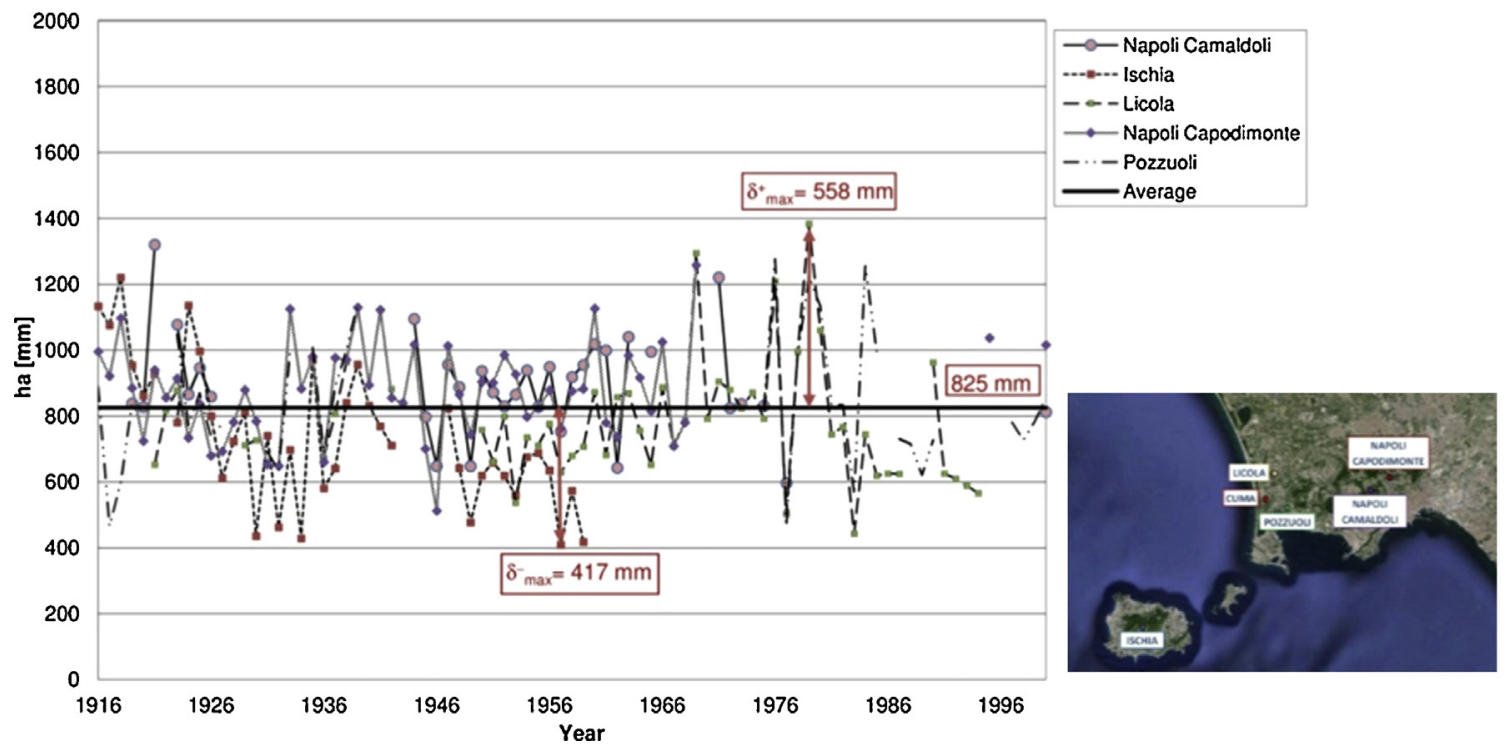

Fig. 8. Cumulative yearly rainfalls in Cumae region between 1916-2006. 
person into the pools is estimated to be an hour (frigidarium and calidarium). If each person occupied an average surface area of 0.36 $\mathrm{m}^{2}$ (assuming a square with sides of $0.60 \mathrm{~m}$ ), increasing the value of $30 \%$, each person could occupy a minimum area of $0.47 \mathrm{~m}^{2}$ inside the pools. Since the total area of the pools is $92.5 \mathrm{~m}^{2}$, a maximum of 198 people could be simultaneously present.

Assuming that $160 \mathrm{l}\left(0.16 \mathrm{~m}^{3}\right)$ of water were used per day for personal care, the necessary exchange of water every hour, corresponding to $31.62 \mathrm{~m}^{3}$, was obtained by multiplying the water volume necessary for each person/bath $(160 \mathrm{l} / \mathrm{d})$ by the number of users that could have been simultaneously present in the pools of the Forum of Cumae. Multiplying the number of people present at the same time within $12 \mathrm{~h}$ of bath operation, the total number of users was equal to 2372 . The daily water flow necessary for the Roman bath function, inferred from these values, corresponded to $379.49 \mathrm{~m}^{3} /$ d, i.e. $4.39 \mathrm{l} / \mathrm{s}$. The cistern of the Forum bath, therefore, with a volume of $525 \mathrm{~m}^{3}$ of water, was sufficient to supply water for about 1 day. Based on the aforementioned data, Cumae could host more than 2000 inhabitants. The baths could attend a maximum of 2372 users per day, which was partly composed of the visitors participating in city trade.

The per capita water supply was evaluated considering two reference values:

- the value of quinaria;

- the per capita water supply of Pompeii [11].

According to Di Fenizio [26] and Rodgers [27], a quinaria corresponded to a flow rate of $0.48 \mathrm{l} / \mathrm{s}$. Pompeii had about 12,000 inhabitants and the daily flow rate (calculated according to the new conduits) was equal to $6460 \mathrm{~m}^{3} / \mathrm{d}$. The per capita water supply of Pompeii corresponding to $0.54 \mathrm{~m}^{3} / \mathrm{d}$ per person was obtained by dividing the daily flow rate by the number of inhabitants [25].

The difference between the two values is undoubtedly due to the fact that the quinaria takes into account only the personal consumption of water whereas the value for the city of Pompeii was calculated as the ratio between the overall scopes and the number of inhabitants - including the water used for domestic purposes, for public purposes and for decorative ponds and fountains.

It has been estimated that 10,000 sailors and 10,000 civilians constituted the population of Misenum. These 20,000 people would have had the same per capita water supply calculated for Pompeii, i.e. $0.54 \mathrm{~m}^{3} / \mathrm{d}$ per person. The daily flow should have been 10,767 $\mathrm{m}^{3} /$ d, i.e. $125 \mathrm{l} / \mathrm{s}$. This flow of water would have required more than a day to replenish the Piscina Mirabilis.

Another known datum is that the total population of Nola, Acerra, Atella, Naples, Pozzuoli, Cumae, Baia and Misenum, in the first century AD, exceeded 200,000 people [22], excluding Pompeii and Herculaneum, which, at the time, had respectively 12,000 and 5000 inhabitants [28].

The total population served by Serino Aqueduct would have thus met or exceeded 217,000 people. Although the other cities were not all similar to Pompeii, our study considered that the per capita water supply was of about $0.54 \mathrm{~m}^{3} /(\mathrm{d}$ per person).

An identical per capita water supply was provided via the Augus$\tan$ Aqueduct by a total flow rate of $1352 \mathrm{l} / \mathrm{s}$. The current discharge of "Acquaro-Pelosi" source is $900 \mathrm{l} / \mathrm{s}$ [29]. The two values are wellmatching since the source has been in use for over 2000 years.

Assuming that during the first and second centuries $A D$, the ancient city of Cumae had more than 2000 inhabitants with a per capita water supply corresponding to $0.54 \mathrm{~m}^{3} / \mathrm{d}$, the water flow of the branch aqueduct directed to Cumae from the main stretch of the Serino aqueduct could be estimated at $1076.7 \mathrm{~m}^{3} / \mathrm{d}$.

\section{Conclusions}

A hydrological analysis was carried out in order to exactly assess route, flow and uses of the water conveyed by the Aqua Augusta through the city of Cumae.

According to this analysis, the historical records regarding a branch of the Augustan Aqueduct, which would have reached the city of Cumae, were confirmed. The water flow of the branch aqueduct directed to Cumae from the main stretch of the Serino aqueduct was estimated corresponding to $12 \mathrm{l} / \mathrm{s}$.

\section{Acknowledgments}

Authors acknowledge the PON Aquasystem project (Gestione Integrata del Ciclo delle Acque finalizzata all'Uso Sostenibile delle Risorse, all'Ottimizzazione Energetica, al Monitoraggio e Controllo della Qualità dell'Acqua nei Sistemi Acquedottistici e nelle reti di Drenaggio Urbano) funded by PON R\&C 2007-2013, Smart cities and communities and social innovation.

\section{References}

[1] G. Lofrano, J. Brown, Wastewater management through the ages: a history of humankind, Sci. Total Environ. 408 (2010) 5254-5264.

[2] G. Lofrano, G. De Feo, J. Brown, Water pathways through the ages: From early aqueducts to next generation of wastewater treatment plants. Advances in water treatment and pollution prevention, Springer, 2012, pp. 37-54.

[3] A.T. Hodge, Roman aqueducts \& water supply, Bristol Classical Press, 2002.

[4] J. Brown, G. Lofrano, Overview of wastewater management through the ages World environmental and water resources congress 2015: floods, droughts, and ecosystems, in: Proceedings of the 2015 World Environmental and Water Resources Congress, 2015, pp. 125-135.

[5] K. Kollyropoulos, G. Antoniou, I. Kalavrouziotis, J. Krasilnikoff, D. Koutsoyiannis, A. Angelakis, Hydraulic characteristics of the drainage systems of ancient hellenic theatres: case study of the theatre of dionysus and its implications, J. Irrig. Drain Eng. (2015), 10.1061/(ASCE)IR. 1943-4774.0000906, 04015018

[6] A.O. Koloski-Ostrow, N. De Haan, G. De Kleijn, S. Piras, Water in the Roman town: new research from Cura Aquarum and the Frontinus Society, J. Roman Archaeol. 10 (1997) 181-191.

[7] H. Manderscheid, The water management of Greek and Roman baths, in: O. Wikander (Ed.), Handbook of ancient water technology, Leiden, Boston, and Köln, 2000, pp. 467-535

[8] R.D. Hansen, Water and wastewater systems in Imperial Rome, Water Res. Bull. Am. Water Res. Assoc. 19 (2) (1983).

[9] Y. Gorokhovich, A. Alexopoulos, V. Gikas, P. Gikas, A.N. Angelakis, Water supply and use in the Roman city of Aptera, Hellas: the mystery of the ancient water system, in: Proc. of the 3rd IWA International symposium on water and wastewater technologies in ancient civilizations, March 22-25, 2012, Istanbul, Turkey, 2012, pp. 380-386

[10] R. Coates-Stephens, The walls and aqueducts of Rome in the Early Middle Ages, AD 500-1000, J. Roman Stud. 88 (1998) 166-178.

[11] G. De Feo, R.M. Napoli, Historical development of the Augustan Aqueduct in Southern Italy: 20 centuries of works from Serino to Naples, Water Sci. Technol. Water Supply 7 (1) (2007) 131-138.

[12] G. Libertini, B. Miccio, N. Leone, G. De Feo, The Augustan aqueduct in the context of road system and urbanization of the served territory in Southern Italy, in: Proceedings of the IWA regional symposium on water, wastewater and environment: tradition and culture, 22-24 March 2014, Patrass (Greece), 2014.

[13] F. De Paola, M. Giugni, M.E. Cornacchia, G. Lofrano, The water supply of ancien Cumae: the case study of the Forum bath, in: Proceedings of the IWA regional symposium on water, wastewater and environment: tradition and culture, 2224 March, Patrass (Greece), 2014.

[14] W.F. Lorenz, G. De Feo, E. Baros, S. De Gisi, Ancient Pompeii water supply: sources, routes, hydraulics of the aqueducts, Wright Paleohydrological Institute, 2012

[15] B. Miccio, U. Potenza, Gli acquedotti di Napoli, Azienda Municipalizzata Acquedotto di Napoli, Milan, Italy, 1994.

[16] G. Bodon, I. Riera, P. Zanoviello, Utilitas necessaria. Sistemi idraulici nell'Italia romana, Ed. Progetto Quarta Dimensione, 1994.

[17] L. Mays, G.P. Antoniou, A.N. Angelakis, History of water cisterns: legacies and lessons, Water 5 (2013) 1916-1940.

[18] F. Abbate, Primi studi sull'acquedotto Claudio: rapporto al signor sindaco di Napoli, Stamperia dell'Iride, Naples, Italy, 1862

[19] G.G. Fagan, Hygienic conditions in Roman public baths, in: G.C.M. Jansen (Ed.), Cura Aquarum in Sicilia, Leiden, 2000, pp. 281-288.

[20] P. Caputo, R. Morichi, R. Paone, P. Rispoli, Cuma e il suo parco archeologico. Un territorio e le sue testimonianze, Bardi Editore, Rome (Italy), 1996.

[21] G.G. Fagan, Bathing in public in the Roman world, University of Michigan Press, 2002. 
[22] R. Tölle-Kastenbein, Archeologia dell'acqua. La cultura idraulica nel mondo Classico, Longanesi \& C, Milan, Italy, 2005.

[23] G. De Martino, F. De Paola, N. Fontana, G. Marini, A. Ranucci, L'efficienza delle vasche di prima pioggia per la riduzione dell'impatto inquinante sui corpi idrici, in: Proceedings of the XXXI Convegno Nazionale di Idraulica e Costruzioni Idrauliche, 9-12 September 2008, Perugia (Italy), 2008.

[24] B.J. Hyndman, Y. Khandakar, Automatic time series forecasting: the forecast package for R, J. Stat. Software 27 (3.) (2008).

[25] J.P. Adam, Roman building. Materials and techniques, Routledge, 2004, ISBN 978-0-415-20866-6.

[26] C. Di Fenizio, Sulla portata degli acquedotti romani e determinazione della quinaria, Tip. Del Genio Civile, 1916.
[27] R.H. Rodgers, Copia Aquarum: Frontinus' measurements and the perspective of capacity, Trans. Am. Philos. Assoc. 116 (1986) 353.

[28] L. Capasso, I fuggiaschi di Ercolano. Paleobiologia delle vittime dell'eruzione vulcanica del 79 d.C., L'Erma di Bretschneider, 2001.

[29] P. d'Ambito, Piano d'Ambito, ATO1 05/2003, 2003 http://www. atocaloreirpino.it/documenti/PA-Volume_I.pdf.

[30] L.W. Mays, M. Sklivaniotis, A.N. Angelakis, Water for human consumption through the history, in: Evolution of water supply throughout millennia, IWA Publishing, London, UK, 2012, pp. 19-42 [Ch. 2].

[31] G. De Feo, A.N. Angelakis, G.P. Antoniou, F. El-Gohary, B. Haut, C.W. Passchier, Xiao Yun Zheng, Historical and technical notes on aqueducts from prehistoric to medieval times, Water 5 (4) (2013) 1996-2025. 